\title{
ARE ACCOUNTING SERVICES THREATENED BY MOVING TO SHARED SERVICE CENTERS? - AN EMPIRICAL EVIDENCE OF CZECH COMPANIES
}

\section{MICHAL ŠINDELÁŘ, BARBORA JANASOVÁ}

\begin{abstract}
:
The article assesses key aspects of shared service center concept within the accounting area from perspective of user unit. Based on the analysis of theoretical concepts related to types of financial services suitable for moving to shared service centers, the hypotheses are formulated. Hypotheses are verified by empirical research and tested by appropriate statistical methods as odds ratio (OR) and Fisher's exact test. The results show that companies prefer to move codify-able and routine activities to shared service centers. The most common activity transferred to shared service centers is receivables management. The results of analysis enable to get an opinion on the usefulness of shared service centers used by Czech companies.
\end{abstract}

\section{Keywords:}

Shared service centers, sourcing models in accounting, odds ratio, complexity of services, codification of services

JEL Classification: M41

\section{Authors:}

MICHAL ŠINDELÁŘ, University of Economics, Prague, Czech Republic, Email: michal.sindelar@vse.cz BARBORA JANASOVÁ, University of Economics, Prague, Czech Republic, Email:

barbora.janasova@gmail.com

\section{Citation:}

MICHAL ŠINDELÁŘ, BARBORA JANASOVÁ (2020). Are accounting services threatened by moving to shared service centers? - An empirical evidence of czech companies. International Journal of Economic Sciences, Vol. IX(2), pp. 111-127., 10.20472/ES.2020.9.2.007 


\section{Introduction}

The trend of moving jobs from developed markets to lower cost markets can already be observed for several decades, especially in the manufacturing industry. On the other hand, labor in the service sector has been considered relatively secured. Professionals and specialists in various service sectors believed that their education, experience and knowledge could prevent the transfer of their jobs into the low-cost markets. This presumption has been proven to be false as we can see many foreign service centers opened in the last decade.

Development of shared service centers (SSC) is permitted by rapid development of communication technologies, which made the export of services simpler and cheaper. While there are still some barriers with the export of the goods, the marginal costs of transferring services are very low. The impact of this development on individual entrepreneurs in Czech Republic is analyzed by Belás et al. (2015). Due to information technology, global market is accessible not only to big multinationals, but also to local companies. This trend forced the global companies to use resources from the offshore locations. The concept of shared service centers is not suitable for every company. The role can play culture, social or other aspects, some companies are too small to realize economies of scale or some might be already too efficient to realize more savings. Before any decision is made, company should be fully aware of the associated cost related to the usage of shared service centers. We do not only mean the direct cost (e.g. payment to suppliers), but also additional related cost of this relationship. Those costs are often hidden.

In accounting, the establishment of SSC might be a step forward to complete replacement of human bookkeepers by the robots, as predicted by Frey and Osborne (2017). The results of our survey indicate that companies are aware, that certain activities in accounting cycle are suitable candidates to automatized processing at SSC. The accounting services, especially the ones, that are easy to codify and routine, are threatened by moving to SSC. Our survey indicates, that the best candidate are the services connected to receivables management. Surprisingly, the activities connected with fix assets companies recognize as suitable to transfer to SSC although this activity is marked as complex.

This paper aims to assess the usage of the shared service centers by Czech companies within various accounting areas. Emphasis is placed on assessment of which accounting services are the most suitable for transfer to service centers. The introduction, which briefly define history, positive and negative aspects of the use of shared service centers, is followed by literature review. Literature review contains the definition of shared service centers and the overview of economic theories that try to explain the expansion of shared service centers. This part is completed by formulating research hypotheses. This part is followed by analysis of questionnaire survey by using the appropriate statistical methods for evaluation. Research outcome and discussion shows the results of the empirical survey. The most important findings are summarized in conclusion.

\section{$2 \quad$ Literature review}

\subsection{Definition of shared services}

Shared services are operational approach of centralizing administrative and business processes that were once carried out in separate divisions or locations (Oshri et al., 2011). When centers are well managed, they contribute to the cost savings and in some cases, they might even 
generate revenues. Bergeron (2003) offers the alternative definition of the shared services. He evaluates this concept as concentration of part of the services to a newly created semiautonomous entity, which should be able to compete in the market. The aim is to increase efficiency, realize cost savings and create value while providing first class services to the internal customers.

Similarly, Schulmann (1999) defines the shared service centers as a concentration of resources in order to execute activities across the whole company (whole Group). Their aim is to provide top quality services with the lowest possible cost for the huge number of internal partners and eventually satisfy the external customers and increase the value of the whole company. Quinn and Cooke (1999) see the concept of shared services as the method of sharing the resources within the Group in contrary to provision the services in many multiple independent entities (subsidiaries) of the Group.

\subsection{Theoretical background of the concept}

There are several theoretical concepts applicable to the model of shared service centers. Figure 1 contains the overview of applicable theories. The main concepts are economies of scale, transaction cost analysis or agency theory. Additionally, there are also sociological and managerial theories, which could be applicable. There is no single comprehensive theoretical concept which would describe the complexity of the shared service model.

\section{Figure 1 Summary of applicable theories}

\section{Economies of scale (Clark, 1907; Knigth, 1921)}

-Profit-maximizing firm trying to optimize the inputs, outputs and their prices. Economies of scale exist not only within the company but also outside the company. According to this theory, shared service centre therefore can afford to buy more sophisticated accounting software, and still provide services at a low cost level.

Transaction cost analysis (Coase, 1937)

- Using the market and its pricing mechanism is not free, but entails certain costs. The company will use its own resources to activities for which the total cost (including transaction costs) is lower than the acquisition of the activity on the external market.

Agency theory (Jensen and Meckling, 1976)

-This theory explains primarily the necessity of control of work performed by the shared service center.

Theory of resources (Penrose, 1959)

- According to this theory it is preferable the ownership of resources which mean the competitive advantage. Shared service center should be used only for minimum amount of resources.

\section{Sociological and managerial theories}

- The theory of social networks (Granovetter, 1973) explains the influence of shared service centres from the point of relations among employees.

- Social exchange theory (Gouldner, 1960) explains the relation between staff turnover (typical for shared service center) and the quality of performed work.

\section{Source Own processing based on applicable theories}

Transaction cost analysis prefers the minimal cost (Williamson, 1975). Many research proves that costs are the main drivers of decisions related to usage of shared service centers (Mann, 2003; Yourdon, 2004). According to transaction cost analysis, structure of company is primarily 
determined by external factors. Kotabe et al. (1998) and Murray and Kotabe (1999) use modified version of transaction cost analysis in their research. They focus on potential changes in efficiency in relation to the various types of resourcing. Murray and Kotabe (1999) evaluate internal sources placed in various locations. To transfer their approach to accounting services, they compare traditional accounting department with placing a shared accounting service center into the low-cost location. They concluded that transactional cost analysis is widely applicable to the transfer of tangible goods, however less applicable to transfer of intangible goods. Due to the fact that services have more in common with intangibles, applicability of transactional cost is limited. Kotabe et al. (1998) compares various types of ownership and evaluates the options of providing services internally (own shared service center) or externally (outsourcing).

On the other hand, theory of resources prefers internal resources. Company structures are based on internal factors (on contrary to external factors in transactional cost analysis). Ownership of resources is considered as important competitive advantage (Erramilli and Rao, 1993; Gatignon and Anderson, 1988), therefore there is a strong preference to keep the ownership rather than the services move to the foreign markets. According to Madhok (1997), theory of resources better explains decisions related to outsourcing versus insourcing. This is in line with Ekeledo and Sivakumar (2004) and their empirical research of US manufacturing companies entering foreign markets.

Both above mentioned concepts are applicable. They are not contradicting, they are complementary (Kogut and Zander, 1993; Madhok, 1997; Williamson, 1999). Empirical research of Japanese automotive industry (Nagaoka, 2008) introduces a third concept to the options of "buy or do it yourself" approach. The third option is also called „relational contracting“. This means long term contract based on very good relationships. It is very close vendor-customer relationship, mutually beneficial and running for a long time. This relationship is a key factor of successful business process outsourcing, including outsourcing of accounting services.

\section{Factors and hypothesis related to transferability of accounting services to SSC}

Understanding of each sourcing model is equally important as understanding of which types of accounting services are suitable for transfer to shared service center. Harritz (2018), Metters (2008) and Mezihorak (2017) mention that companies typically transfer services, which are not critical for the company and which do not represent any competitive advantage. The main reason is that know-how related to transferred service is mostly lost.

Additional important factor in decision making process related to transfer of the service is a scale of this service. In case the scale is too small, cost related to setting up a share center or looking for a proper supplier and cost related to new established processes will not be paid off. On the other hand, transfer of the service might mean additional levels of management and therefore higher than expected cost.

Services, which are prone to constant changes of technology, are a good candidate for transfer. The reason is that own department rarely has the capacity to cooperate with constantly changing technologies. The only exception is situation, where these services are the critical source of the business or alternatively are the key source of competitive advantage. Additionally, good candidates for transfer are the services which show a big variability of resource need during the cycle, e.g. activity which requires 50 employees one week and only 10 employees the following week. The company need to recruit 50 employees however 40 of them have nothing to do during 
the second week. In this scenario, shared service centers might be able to use free resources for a contra-cyclic client.

Metters (2008) additionally states that services which require constant communication between provider and consumer of a service are not suitable for transfer. The main reasons are possible cultural differences, various time zones and additional communication barriers which might reduce the model efficiency.

Based on the research of Aron and Singh (2005), we can see that companies pay a huge attention to the selection of place (location of shared service center), but they do not pay enough attention to the selection of proper service suitable for transfer. Companies have difficulties in selecting the key services for a company. This fact concludes also Owens (2013), who analyzed the positive and negative aspects of usage of shared service centers in the Group of companies. The recent research focuses on expenses (Ganti, 2016) and control of the shared service center (Kastberg, 2014). The research in the area of shared services is not only focused on business sector but also tries to find aspects, how to extend this topic to public sector (Raudla and Tammel, 2015).

\subsection{Support services}

In order to properly distinguish between key and support services, the specifics of a particular company need to be taken into account. However, there are several generic concepts which could be used. One of them is Porter's value chain analysis (Porter, 1985), in which Porter sets up input and output services including logistics, manufacturing, marketing and selling as key services. On the other hand, he sets resource planning and securing, technology \& development and company infrastructure as supporting services. Alternative approach is offered by Vyskočil and Štrup (2003), which is perhaps more applicable to only service companies. They divide services into direct and indirect. Direct services directly contribute to the company value creation. Indirect services support proper provision of direct services.

Aron and Singh (2005) suggest that company could evaluate services in two dimensions: firstly, their potential for value creation and secondly, their importance for value sustainability. Services, which are important from the customer value point of view should not be transferred. Examples could be cash-flow prediction or management of working capital. Similarly, Willcocks et al. (2011) suggest separating services which are key to the company operations. This services should stay „in house“.

\subsection{Codification of services}

In order to reduce operational risk related to usage of shared service centers it is important to assess the service from the point of codify-ability. Codification is concentration of knowledge into structures, which allows transferability of services (Boisot, 1986). Process of codification includes usage of various models, codes, flow charts etc. (Ancori et al., 2000) and means translation of activities or rules into procedures, specifications and documentations (Kogut and Zander, 1992; Lam (1997). Possible level of codification depends on the type of knowledge to be transferred. Implicit knowledge is gained via experience, it is often hidden and hardly codify-able. On the other hand, explicit knowledge could be very well shared (Nelson and Winter, 1982).

Research in the area of information technology describes various tools used in business process codification. Malone et al. (1999) state that description of activities via flow charts and diagrams enabled evolution of so-called process grammar. This resulted in the fact that even some more 
complex services could be codified. Codification as a mean of transfer of knowledge resulted in a change from classic ways of working into division of labor widely used in shared service centers (Cohendet and Steinmueller, 2000; Malerba and Orsenigo, 2000).

Codification is relevant in both domestic and foreign markets. It enables globalization of local knowledge and reduces the time needed for its transfer (Cohendet and Steinmueller, 2000). Process of codification via decomposition, analysis and synthesis of processes should lead to more efficient provision of services. Codification is an enabler of entering a service contract since it provides visualization and description of a service level which could be expected from a supplier (Boisot, 1986; Cowan et al., 2000). Codified processes are more easily measurable. Based on the above statements we conclude following hypothesis.

H1: It is more beneficial to transfer well codify-able services rather than less codify-able services into shared service centers.

\subsection{Complexity of services}

There are various types of activities within the accounting services. They differ a lot in terms of complexity. In case of the activity has sequence of steps, which are dependent, the activity is complex. Among the factors or dependence might be timing, profitability of a company or involvement of other employees. Complex services are very hard to standardize. On contrary to routine services, which tend to repeat the same way very often, complex services are not that repetitive and predictable.

Complex services are difficult to describe in detail in contracts. They are also harder to measure. If complex services are transferred into shared service center, the associated operational risk is higher. The alternative view divides services into transparent and non-transparent. Well measurable and well codify-able transparent services are most suitable for transfer to shared service center (Nelson and Winter, 1982). On the other hand, non-transparent services despite of the well codify-ability, cannot be measured at the end (especially in terms of quality). They represent mostly the average operational risk, which could be reduced e.g. by regular checking of samples, but this approach might increase cost. Ideally in these cases the expectations of cooperation should be clearly clarified, and proper system of penalties and rewards should be established.

Due to their applicability at wide market routine and repetitive services allow economies of scale. Williamson (1985) describes the dimensions of processes which determine who is able to provide the service in the most efficient way. In case of the unclarity in the definition of service or measurement it is probable, that this service would not be transferable to the shared service center. On the other hand, simple and measurable services would be transferable to the shared service center. Based on the above statements we concluded the following hypothesis:

H2: It is more beneficial to transfer routine services rather than complex services into shared service centers

\section{$4 \quad$ Methodology and data}

Data related to testing above mentioned hypothesis are not publicly available. Due to this fact, the on-line survey method was selected. The advantages of this method are:

- Full anonymity of respondents allows to answer honestly and openly; 
- In comparison to paper form of survey, respondents spend less time opening, filling and sending it (overall 8-10 minutes at our case);

- In comparison to the sending the survey as an attachment to e-mail, on-line survey does not consume an e-mail memory of the respondent.

\subsection{Data collection}

Research focuses on big and medium companies. Based on the theory and recent research the big multinationals (Oshri et al., 2011) are the main users of shared service centers. Therefore, we focused on Czech companies in which at least one for the following conditions is met:

- Number of employees higher than 1000 ;

- Yearly revenue higher than 150 mil CZK;

- Total assets higher than 500 mil CZK.

These criteria fulfilled 361 Czech companies. We had used European database Amadeus. Due to the fact, that this database does not provide contact details of companies, we had to look for those details individually. We could not find contact details of 14 companies (4\%).

Most of the companies was contacted via e-mail. Some companies do not provide e-mail addresses and prefer alternative ways of contacting them, e.g. on-line form. We respected this and contacted them via their forms. We also tried to avoid selecting our emails as SPAM therefore the maximum number of companies addressed in one e-mail (as blind copy) was 15. In total, we had contacted 339 companies.

We had used software Survio for creation our on-line survey. Apart from standard survey statistics, this software provides the information how many respondents click to the link however did not fill it in. It was 133 respondents (39\%). Survey was filled by 63 respondents (19\%), however complete usable number of filled surveys was $38(11 \%)$. This return rate is of course the typical range (Lane, 2007). Table 1 shows the data collection process.

During the creation of our survey we tried to stick the rules related to on-line surveys (Dillman, 2011). There were 14 questions in our survey. Questions were consistent and build up in logical order.

For clearer understanding, accounting processes had been divided into the following areas:

- Billing;

- Accounts payable;

- Fixed assets;

- General ledger (fin. accounting);

- Accounts receivable (incl. banking);

- Travel \& other expenses;

- Internal reporting/controlling/MI (management information);

- External reporting (statutory, tax). 
Table 1 Data collection

\begin{tabular}{lrr}
\hline & Number & Percent (\%) \\
\hline Number of companies based on criteria & 361 & 100 \\
Number of companies without contact details & 14 & 4 \\
Number of companies with contact details & 347 & 96 \\
\hline & & 89 \\
\hline E-mails sent & 310 & 11 \\
On-line form filled & 37 & 5 \\
E-mails undelivered - 1. round & 17 & 3 \\
E-mails undelivered - 2. round & 8 & 97 \\
E-mails delivered & 302 & \\
\hline
\end{tabular}

\section{Number of contacted companies}

Remainder via e-mail

Remainder via phone

Number of companies entering survey without filling it

Number of filled surveys (incl. incomplete)
339

280

22

133

63

38
100

83

6

39

Number of usable filled surveys

\section{Source Own processing}

\subsection{Methodology}

Hypotheses were tested by using statistical methods. As appropriate statistical tools were chosen the Odds ratio test (the OR) and the Fisher's exact test. The Odds ratio describes the interdependence of two variables based on the following contingency table (Table 2).

Table 2 Pivot table for Odds ratio

\begin{tabular}{llll}
\hline \multirow{2}{*}{$\begin{array}{c}\text { Random variable } \mathbf{X} \\
\end{array}$} & \multicolumn{2}{c}{ Random variable $\mathbf{Y}$} & \multirow{2}{*}{ Total } \\
\cline { 2 - 3 } & $\mathbf{Y = 1}$ & $\mathbf{Y = 2}$ & \\
\hline $\mathrm{X}=1$ & $\mathrm{n}_{11}$ & $\mathrm{n}_{12}$ & $\mathrm{n}_{1+}$ \\
$\mathbf{X}=2$ & $\mathrm{n}_{21}$ & $\mathrm{n}_{22}$ & $\mathrm{n}_{2+}$ \\
Total & $\mathbf{n}_{\mathbf{+ 1}}$ & $\mathbf{n}_{+2}$ & $\mathbf{n}$ \\
\hline
\end{tabular}

Source: Own processing

Risk ratio $(R R)$ then represents the ratio of the probability of one possibility (event occurred) to the second (event not occurred). Thus, for example, RR shows the probability of abandonment of routine activity versus its disabandonment. For mathematical expression of odds ratio, we can apply this equation (1). 


$$
O R=\frac{R R_{1}}{R R_{2}}=\frac{n_{11} * n_{22}}{n_{12} * n_{21}}
$$

where $\mathrm{n}=$ frequency of answers

The Odds ratio (or the risk of occurrence) for two different values of the two variables is complementary in inverted value, e.g. OR of abandonment routine activities is direct reciprocal of disabandonment of complex activities. For statistical verification, we determine null $(\mathrm{H} 0)$ and alternative hypothesis $(\mathrm{H} 1)$. $\mathrm{HO}$ says that the ratio of one variable is the same for different values of the second variables - the variables are independent. Then we can write (equation 2)

$$
\mathrm{H}_{0}: \mathrm{OR}=1 ; \mathrm{H}_{1}: \mathrm{OR}>1
$$

For testing single-sided hypothesis of independence (when relatively small amount of measurement) the Fisher's exact test, is used. The null hypothesis is, in the case of Fisher's exact test, the independence of the monitored variables. This means, if $\mathrm{HO}$ is valid, the observed frequencies should correspond to the expected rates. Then we can calculate $p^{*}$ value for all possible combinations in the contingency table while maintaining the marginal frequency (equation 3). The test statistics or $p$-value of Fisher's exact test is the sum of $p^{*}$ probabilities lower than or equal to the value $p+$ probability which belongs to the contingency table constructed from measured values (equation 4). To reject hypothesis $\mathrm{H} 0$, we require the probability $\mathrm{p}$ below the level of significance $(\alpha=0,05)$.

$$
\mathrm{p}^{*}=\mathrm{p}^{+}=\frac{\left(\mathrm{n}_{11} * \mathrm{n}_{12}\right) ! *\left(\mathrm{n}_{11} * \mathrm{n}_{21}\right) ! *\left(\mathrm{n}_{21} * \mathrm{n}_{22}\right) ! *\left(\mathrm{n}_{12} * \mathrm{n}_{22}\right) !}{\mathrm{n} ! * \mathrm{n}_{11} ! * \mathrm{n}_{12} ! * \mathrm{n}_{21} ! * \mathrm{n}_{22} !}
$$

where $\mathrm{n}=$ frequency of answers

$\mathrm{p}^{*}=$ different probabilities while maintaining marginal frequencies

$\mathrm{p}^{+}=$probability belonging to measured values

$$
\mathrm{p}=\sum\left(\mathrm{p}^{*}<\mathrm{p}^{+}\right)
$$

where $p=$ the test statistics of Fisher's exact test

$\mathrm{p}^{*}=$ different probabilities while maintaining marginal frequencies

$\mathrm{p}^{+}=$probability belonging to measured values

\section{$5 \quad$ Results and discussion}

\subsection{The profile of respondents in relation to the size of the company}

The survey contained several questions that pointed to get a basic picture of the analyzed sample. As the most interesting there may be considered the profile of the respondents (companies) in relation to the size of the company. The size has been investigated in relation to the number of employees, annual sales and the total assets.

The number of employees could be assigned to one of six categories. Based on the selected criteria it is not surprising that the largest share has of the companies with number of employees more than 1000 (24\%). Relatively high is also the category of $501-1000$ employees (18\%). A very high proportion is also in the category of $101-250$ employees $(21 \%)$. The detailed view shows that the companies with high revenues are very often in this category $(101-250$ employees). 
Another important criterion for the selection of large companies is the amount of annual sales. None of the respondents marked the value lower than 500 million CZK, and only one respondent stated the range of 501 million CZK - 1 billion CZK. Most respondents operate with annual revenues of $5-10$ billion CZK.

Last informative question regarding to the size of the respondents is the value of total assets. The most commonly reported value was $1-5$ billion CZK (26\%). Widely there are also the companies with values up to 1 billion CZK, $5-10$ billion CZK and $10-50$ billion CZK. The companies with total assets of over billion CZK are represented only with a few companies. A relatively large number of respondents did not respond to this question (21\%). Clearly are the categories of the size of the companies listed in Table 3.

Table 3 The number of respondents by category

\begin{tabular}{lrlrlr}
\hline $\begin{array}{c}\text { Number of } \\
\text { employees }\end{array}$ & Nr. & \multicolumn{1}{c}{ Annual revenue } & Nr. & \multicolumn{1}{c}{ Total Assets } & Nr. \\
\hline up to 50 & 1 & up to 100 million CZK & 0 & up to 1 billion CZK & 7 \\
$51-100$ & 1 & $101-500$ million CZK & 0 & $1-5$ billion CZK & 10 \\
$101-250$ & 8 & 501 million - 1 billion CZK & 1 & $5-10$ billion CZK & 5 \\
$251-500$ & 5 & $1-5$ billion CZK & 12 & $10-50$ billion CZK & 5 \\
$501-1000$ & 7 & $5-10$ billion CZK & 14 & $50-100$ billion CZK & 1 \\
over 1 000 & 9 & over 10 billion CZK & 9 & over 100 billion CZK & 2 \\
unfilled & 7 & Unfilled & 2 & unfilled & 8 \\
Total & 38 & Total & 38 & Total & 38 \\
\hline
\end{tabular}

Source Own processing

\subsection{Codification of services}

Codification of services can be characterized as the densification of knowledge and experience in the structure of using different models and codes. The result of this process is transfer of activities into the directives, instructions, specifications and documentation. Activities are usually shown in flow-charts, transition and destination diagrams and models. This so-called procedural grammar allows codification of some complex processes. Using of codification also allows the transmission of knowledge and experience and is one of the pillars of the establishment of shared service centers, where is an obvious transition from the classical organization of activities to the structured division of labor. Well describable processes are therefore the ideal candidates to move to SSC.

To assess codification of services, respondents mark each activity separately. The external reporting is marked as the worst describable activity. Only $11 \%$ of respondents believe that external reporting is possible to be described. As less describable is also marked internal reporting. On the contrary, receivables management is evaluated as the best to be described by $87 \%$ of respondents. Also, management of commitment is designated as a well described. Surprisingly, the imaginary third place is occupied by accounting of fixed assets, which respondents identified as well describable in $63 \%$ cases. As well-describable activities can be highlighted also travel and other expenses (indicated by $55 \%$ of respondents) and invoicing to 
the customers (61\% of respondents). Clearly the assessment of descriptiveness is shown in Figure 2.

\section{Figure 2 Well-describable activities}

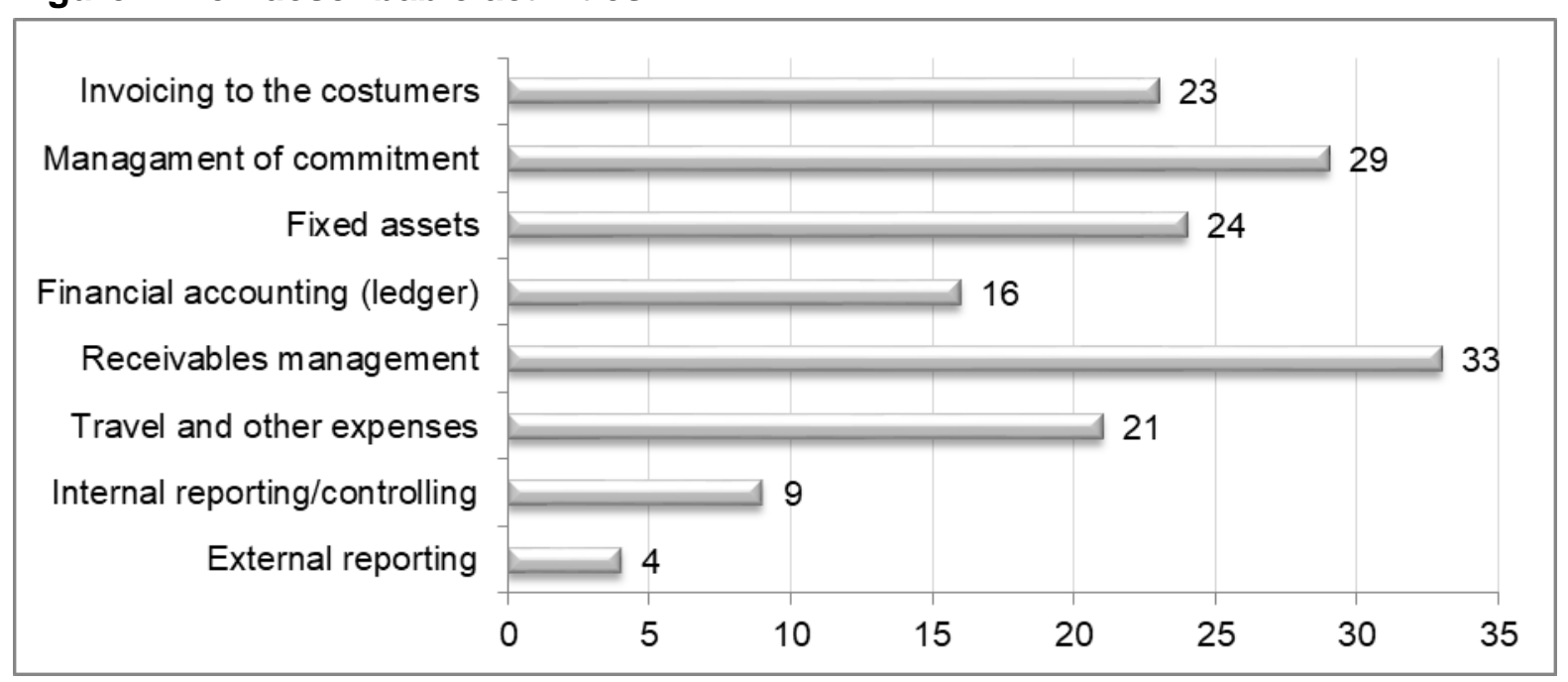

\section{Source Own processing}

Table 4 contains information about for how many respondents it is beneficial to move the activity to shared service center in the context of whether the activity is marked as well describable or not. From the table of frequencies odds ratio $(\mathrm{OR})$ is calculated. Than the lower limit of the confidence interval is given for odds ratio respecting the chosen significance level $(\alpha=0,05)$. The result is statistically more significant if the lower limit is further away from 1 . The analysis shows that the well describable activity is approximately nineteen times greater chance that these activities are beneficial to abandonment than disabandonment in comparison to less describable activities. The relationship between codification of service and its abandonment to SSC is statistically significant. The analysis confirmed the hypothesis $\mathrm{H} 1$ that the companies consider more useful to leave to the shared services center well-describable activities rather than bad describable activities.

Table 4 Abandonment or disabandonment of well and harder describable activities Fisher exact test

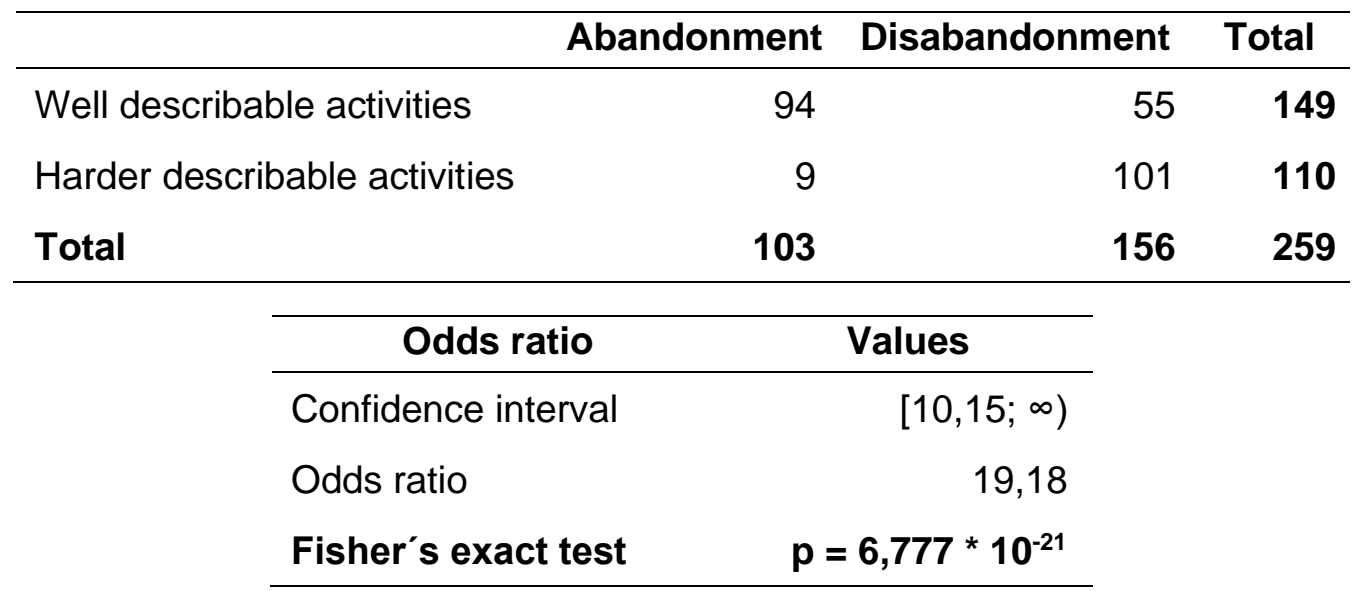

Source Own processing 


\subsection{Complexity of services}

The complex activities are difficult to process to contracts in the necessary detail. So, it is very difficult to control the quality of this activities. The complex activities are characterized by the fact that the sequence of steps is not clearly arranged and depends on many various factors. These factors are e.g. timing, present efficiency or the necessity of involving more employees. When the activity is more complex, then it is more difficult to standardize the activity in any way. Contrary of the complex activities there are routine activities.

In the questionnaire respondents evaluate, which activities they consider to be complex. External reporting was marked as complex activity by $87 \%$ of respondents. Similarly, $84 \%$ of respondents rate the internal reporting/controlling as complex activity. Furthermore, according to the results, we can state that complex activities are financial accounting $(71 \%)$ and fixed assets $(51 \%)$. On the other side, the survey shows that among routine activities we can place the receivables management (only $5 \%$ respondents marked it as complex activity), management of commitment (16\%), eventually invoicing to the costumer (26\%) and travel and other expenses (29\%). The results are shows in the Figure 3.

\section{Figure 3 Complex activities}

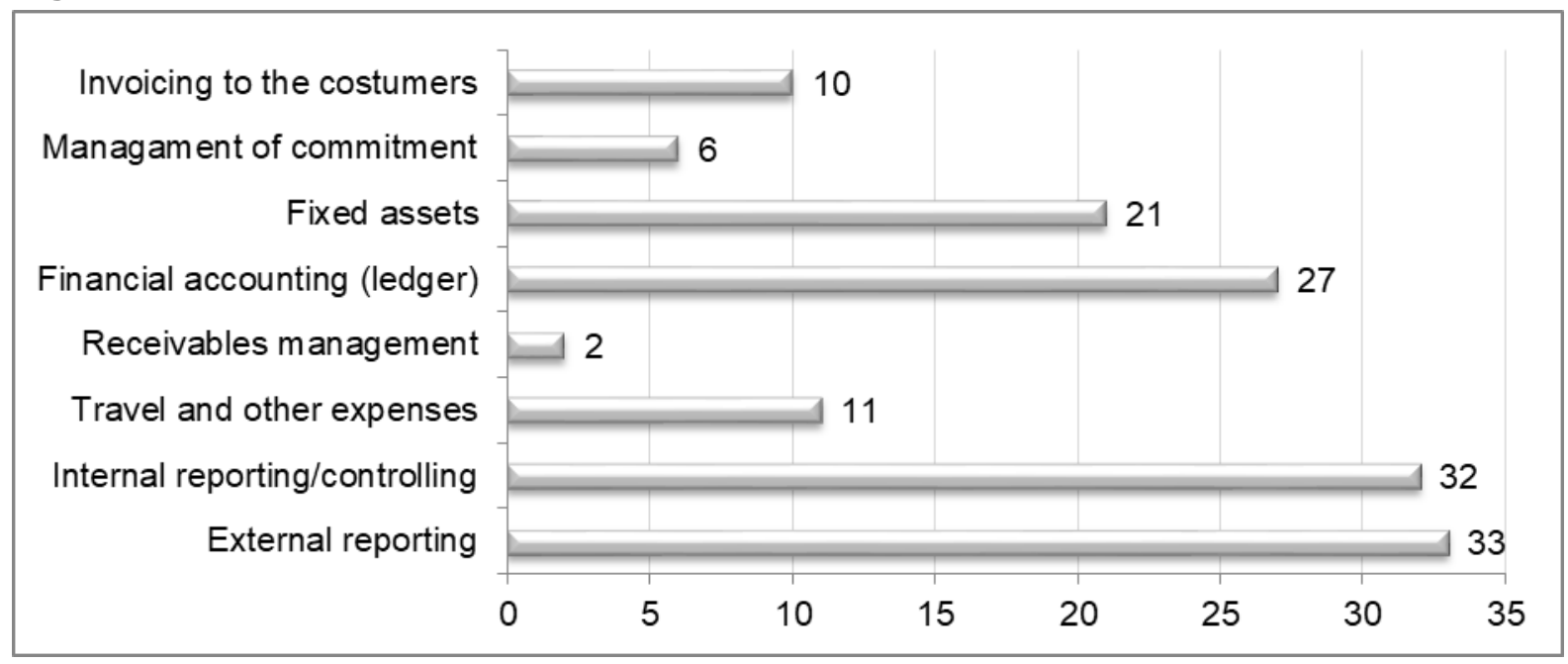

Source Own processing

For testing of the hypothesis $\mathrm{H} 2$ it is necessary to know, how many respondents consider beneficial the abandonment of the accounting activity to SSC in the context, if the accounting activity was marked as complex or routine. From the table of frequencies, the Odds ratio is calculated (Table 5). Than the lower limit of the confidence interval is given for Odds ratio respecting the chosen significance level $(\alpha=0,05)$. The result is statistically more significant if the lower limit is further away from 1. According the results, it is approximately eleven times greater chance that it is beneficial to abandonment routine activities in comparison with complex activities. To verify this conclusion, the Fisher exact test was used, where we again specify the $p$ value. The relationship between complexity of activity and its abandonment to SSC is statistically significant. At the 5\% significance level, we can confirm the hypothesis $\mathrm{H} 2$ that the companies consider more useful to leave to the shared services center routine activities rather than complex activities. 
Table 5 Abandonment or disabandonment of routine or complex activities - Fisher exact test

\begin{tabular}{|c|c|c|c|}
\hline & Abandonment & Disabandonment & Total \\
\hline Routine activity & 83 & 44 & 127 \\
\hline Complex activity & 20 & 120 & 140 \\
\hline Total & 103 & 156 & 267 \\
\hline & atio & Values & \\
\hline Confide & nterval & {$[6,85 ; \infty)$} & \\
\hline Odds re & & 11,32 & \\
\hline Fisher & ct test & $p=2,472 * 10^{-18}$ & \\
\hline
\end{tabular}

Source Own processing

\section{Conclusion}

During the decision-making process whether to use shared service centers, companies need to consider several aspects. Firstly, they need to assess their key motivation, why they would like to move part of their services into a shared service center. In the most cases, the main motivation is cost reduction however some companies are using shared service centers due to access to qualified staff or to access new markets. If the company seeks for skilled and qualified staff, it would not place its service center to a location where demand for a staff is already higher than its supply. Therefore, situation of each company is different.

Additional aspect of the decision-making is to select what type of services are suitable for the transfer to shared service centers. In general, accounting services, typically considered as support type of services, are good candidates. However, it is very important to select the appropriate activities and processes including their correct measurement and controls. Based on the theoretical background and combination of various theories we could conclude that there are several key factors to be considered. Based on the economies of scale the most suitable are routine and repetitive activities. At the same time, based on the transaction cost analysis and theory of resources, the most suitable are activities well codify-able and well definable in manuals and procedures.

One of the most important characteristic of accounting services suitable for transposition to shared service centers is their codification. Well codify-able activity enables reconfiguration and unification of processes, which leads to improvement of the efficiency. Codification enables globalization of local knowledge and reduces the time necessary for transmittal the process. The analysis proves that companies transfer to the shared service centers rather the activities better codify-able than less codify-able and we can confirm the hypothesis $\mathrm{H} 1$. Furthermore, the analysis shows that the best codify-able activity is receivables management $-87 \%$ of respondents consider this activity as well codify-able.

Other attribute relating to the type of activities is their complexity. The analysis proves, that routine activities are more preferable for transfer to shared service center rather than complex activities. According to the analysis we can confirm the hypothesis $\mathrm{H} 2$. As complex activities were mostly chosen external and internal reporting, financial accounting and the area of fixed assets. 
Generally considering above mentioned attributes of accounting activities (complexity and codifyability) in relation with expenses, quality and risks, companies consider receivables management and management of commitment as the most beneficial for removal to the shared service center. The analysis shows both activities convenient for their supplying by shared service centers in comparison with own accounting department.

After the main conclusions, we would like to mention some limitations of performed analysis. At the questionnaire survey, there exists the risk that respondents, who decide to answer the questionnaire, will consider their situation at the analyzed area as more than standard and they will want to present themselves in the good way and they will not be the representatives of statistically neutral sample. This is in the literature known as "self-selection bias" (Ziliak and McCloskey, 2008). We try partly to eliminate this risk by telephone contact with the respondents. Other problematic part of the questionnaire survey is the fact that all chosen companies could not decide about using of shared service center by themselves. Those companies that were obligated to use the shared service center, can prone to the more negative opinion in comparison with companies that make the decision by themselves. The survey is based on the companies that use the shared service center behest the mother company. At the end, we would like to mention, that this article represents only a part of the questionnaire survey. We suppose research in the area of shared service centers in a more detail, e.g. from the view of external auditor. This should help to submit the compacted view on the issue of shared service centers.

\section{Acknowledgement}

The paper is processed as an outcome of the research project "Market failures and their impact on audit quality in the Czech Republic" (IGA VSE F1/25/2019).

\section{References}

Ancori, B., Bureth, A. and Cohendet, P. (2000). The Economics of Knowledge: The Debate about Codification and Tacit Knowledge. Industrial and Corporate Change, 9(2), pp. 255-287. Doi: http://dx.doi.org/10.1093/icc/9.2.255.

Aron, R. and Singh, J. V. (2005). Getting offshoring right. Harward Business Review, 83(12), pp. 135-143.

Belás, J., Bilan, Y., Demjan, V. and Sipko, J. (2015). Entrepreneurship in Sme Segment: Case Study from the Czech Republic and Slovakia. Amfiteatru Economic, 17(38), pp. 308-326.

Bergeron, B. P. (2003). Essentials of shared services. New Jersey, USA: John Wiley \& Sons.

Boisot, M. H. (1986). Markets and Hierarchies in a Cultural Perspective. Organization Studies, 7(2), pp. 135-158. Doi: http://dx.doi.org/10.1177/017084068600700204.

Clark, J. B. (1907). Essentials of Economic Theory. New York, USA: The Macmillan Company. Digitalized by Mises Institute 2013.

Coase, R. H. (1937). The Nature of the Firm. Economica, 4(16), pp. 386-405. Doi: http://dx.doi.org/10.1111/j.1468-0335.1937.tb00002.x.

Cohendet, P. and Steinmueller, W. E. (2000). The Codification of Knowledge: A Conceptual and Empirical Exploration. Industrial and Corporate Change, 9(2), pp. 195-209. Doi: http://dx.doi.org/10.1093/icc/9.2.195.

Cowan, R., David, P. A. and Foray, D. (2000). The Explicit Economics of Knowledge Codification and Tacitness. Industrial and Corporate Change, 9(2), pp. 211-253. Doi: http://dx.doi.org/10.1093/icc/9.2.211. 
Dillman, D. R. (2011). Mail and Internet Surveys. The Tailored Design Method -- 2007 Update with New Internet, Visual, and Mixed-Mode Guide. 2nd ed. New Jersey, USA: John Wiley \& Sons.

Ekeledo, I. and Sivakumar, K. (2004). International Market Entry Mode Strategies of Manufacturing Firms and Service Firms. A Resource-Based Perspective. International Marketing Review, 21(1), pp. 68101. Doi: http://dx.doi.org/10.1108/02651330410522943.

Erramilli, M. K. and Rao, C. P. (1993). Service firms' international entry mode choice: a modified transaction-cost analysis approach. Journal of Marketing, 57(3), pp. 19-38. Doi: http://dx.doi.org/10.1177/002224299305700302.

Frey, C. B. and Osborne, M. A. (2017). The future of employment: How susceptible are jobs to computerisation? Technological Forecasting and Social Change, 114(C), pp. 254-280. Doi: http://dx.doi.org/10.1016/j.techfore.2016.08.019.

Ganti, R. K. (2016). Cost Optimization - Shared Service Center. Management Accountant, 51(9), pp. 37. Doi: 10.33516/maj.v51i9.37-40p.

Gatignon, H. and Anderson, E. (1988). The Multinational Corporations Degree of Control Over Foreign Subsidiaries. An Empirical Test of A Transaction Cost Explanation. Journal of Law, Economics and Organization, 4(2), pp. 153-174.

Gouldner, A. W. (1960). The norm of reciprocity: A preliminary statement. American Sociological Review, 25(16), pp. 161-178. Doi: http://dx.doi.org/10.2307/2092623.

Granovetter, M. (1973). The strength of weak ties. American Journal of Sociology, 78(6), pp. 1360-1380. Doi: http://dx.doi.org/10.1086/225469.

Harritz, D. (2018). Forming and transforming shared services: the performativity of management devices. Journal of Accounting \& Organizational Change, 14(2), pp. 216-233. Doi: http://dx.doi.org/10.1108/JAOC-06-2016-0036.

Jensen, M. C. and Meckling, W. H. (1976). Theory of the Firm: Managerial Behavior, Agency Costs, and Ownership Structure. Journal of Financial Economics, 3(4), pp. 305-360. Doi: http://dx.doi.org/10.1016/0304-405X(76)90026-X.

Kastberg, G. (2014). Framing shared services: Accounting, control and overflows. Critical Perspectives on Accounting, 25(8), pp. 743-756. Doi: http://dx.doi.org/10.1016/j.cpa.2014.01.002.

Knight, F. H. (1921). Risk, Uncertainty, and Profit. Republished in 2006. Boston, USA: Dover Publications Inc.

Kogut, B. and Zander, U. (1992). Knowledge of the Firm, Combinative Capabilities, and the Replication of Technology. Organization Science, 3(3), pp. 383-397. Doi: http://dx.doi.org/10.1287/orsc.3.3.383.

Kogut, B. and Zander, U. (1993). Knowledge of the Firm and the Evolutionary Theory of the Multinational Corporation. Journal of International Business Studies, 24(4), pp. 625-645. Doi: http://dx.doi.org/10.1057/palgrave.jibs.8490248.

Kotabe, J., Murray, J. Y. and Javalgi, R. G. (1998). Global sourcing of services and market performance: an empirical investigation. Journal of International Marketing, 6(4), pp. 10-31. Doi: http://dx.doi.org/10.1177/1069031X9800600406.

Lam, A. (1997). Embedded Firms, Embedded Knowledge: Problems of Collaboration and Knowledge Transfer in Global Cooperative Ventures. Organization Studies, 18(6), pp. 973-996. Doi: http://dx.doi.org/10.1177/017084069701800604.

Lane, S. M. (2007). Defining the Determinants of the Decision to Outsource Intromation Systems Software. A Transaction Cost Perspective. PhD. University of Calgary, Aberta, Canada. 
Madhok, A. (1997). Cost, value and foreign market entry mode: The transaction and the firm. Strategic Management Journal, 18(1), pp. 39-61. Doi: http://dx.doi.org/10.1002/(SICl)10970266(199701)18:1\%3C39::AID-SMJ841\%3E3.0.CO;2-J.

Malerba, F. and Orsenigo, L. (2000). Knowledge, Innovative Activities and Industrial Evolution. Industrial and Corporate Change, 9(2), pp. 289-314. Doi: http://dx.doi.org/10.1093/icc/9.2.289.

Malone, T. W., Crowston, K., Lee, J., Pentland, B., Dellarocas, C., Wyner, G., Quimby, J., Osborn, C. S., Berstein, A., Herman, G., Klein, M. and O’Donnell, E. (1999). Tools for Inventing Organizations. Towards a Handbook of Organizational Processes. Management Science, 45(3), pp. 425-443. Doi: http://dx.doi.org/10.1287/mnsc.45.3.425.

Mann, C. L. (2003). Globalization of IT services and white-collar jobs: The next wave of productivity growth. International Economics Policy Briefs, 11, pp. 1-13.

Metters, R. (2008). A typology of offshoring and outsourcing in electronically transmitted services. Journal of Operations Management, 26(2), pp. 198-211. Doi: http://dx.doi.org/10.1016/j.jom.2007.02.004.

Mezihorak, P. (2017). Competition for control over the labour process as a driver of relocation of activities to a shared services centre. Human Relations, 71(6), pp. 822-844. Doi: http://dx.doi.org/10.1177/0018726717727047.

Murray, J. Y. and Kotabe, M. (1999). Sourcing Strategies of U. S. Service Companies: A Modified Transaction Cost Analysis. Strategic Management Journal, 20(9), pp. 791-809. Doi: http://dx.doi.org/10.1002/(SICI)1097-0266(199909)20:9\%3C791::AID-SMJ49\%3E3.0.CO;2-U.

Nagaoka, S., Takeishi, A. and Noro, Y. (2008). Determinants of firm boundaries: Empirical analysis of the Japanese auto industry from 1984 to 2002. Journal of the Japanese and International Economies, 22(2), pp. 187-206. Doi: http://dx.doi.org/10.1016/j.jjie.2008.03.002.

Nelson, R. R. and Winter, S. G. (1982). An Evolutionary Theory of Economic Change. London, England: Belknap Press:Cambridge MA.

Oshri, I., Kotlarsky, J. and Willcocks, L. P. (2011). The Handbook of Global Outsourcing and Offshoring. New York, USA: Palgrave Macmillan.

Owens, A. (2013). Improving the performance of finance and accounting shared service centres. Journal of Payments Strategy \& Systems, 7(3), pp. 231-250.

Penrose, E. T. (1959). The Theory of the Growth of the Firm. Republished in 2009. New York, USA: Blackwell.

Porter, M. E. (1985). Competitive Advantage: Creating and Sustaining Superior Performance. New York, USA: Free Press.

Raudla, R. and Tammel, K. (2015). Creating shared service centres for public sector accounting. Accounting, Auditing \& Accountability Journal, 28(2), pp. 158-179. Doi: http://dx.doi.org/10.1108/AAAJ-06-2013-1371.

Quinn, B. and Cooke, R. (1999). Shared Services: Mining for Corporate Gold. London, Great Britain: Financial Times Management.

Schulman, D. (1999). Shared Services: Adding Value to the Business Units. New York, USA: Wiley.

Vyskočil, V. K. and Štrup, O. (2003). Podpůrné procesy a snižování režijních nákladů (facility management). 1st ed. Prague, Czech Republic: Professional publishing.

Willcocks, L., Cullen, S. and Craig, A. (2011). The outsourcing enterprice: from cost management to collaborative innovation. London, Great Britain: Palgrave. https://doi.org/10.1057/9780230290570 
Williamson, O. (1975). Markets and Hierarchies: Analysis and Antitrust Implications:a Study in the Economics of Internal Organization. New York, USA: Free Press.

Williamson, O. (1985). The Economic Institutions of Capitalism. Firms, Markets and Relational Contracting. New York, USA: Free Press.

Williamson, O. (1999). Strategy research: governance and competence perspectives. Strategic Management Journal, 20(12), pp. 1087-1108. Doi: http://dx.doi.org/10.1002/(SICl)10970266(199912)20:12\%3C1087::AID-SMJ71\%3E3.0.CO;2-Z.

Yourdon, E. (2004). Outsource: Competing in the Global Productivity Race. New York, USA: Prentice Hall.

Ziliak, S. T. and McCloskey, D. N. (2008). The Cult of Statistical Significance: How the Standard Error Costs Us Jobs. 1st ed. Michigan, USA: University of Michigan Press. 